\title{
The history of modern spinal traction with particular reference to neural disorders
}

\author{
Michael V Shterenshis \\ The Hebrew University - Hadassah Medical School, Jerusalem, Israel
}

\begin{abstract}
The last 200 years of the history of spinal traction is described in the present article. The study starts at the end of the 18th century with the works of JA Venel (1789) who tried to apply the Hippocratic idea to modern surgery. Orthopedic specialists of the last century were mostly preoccupied with corsets and the method gained broader popularity when neurologists paid attention to the similar method of suspension. The Russian neurologist Osip Mochutkovsky described suspension as a method for the treatment of tabes dorsalis in an article published in the Russian magazine 'Vratch' in 1883. His works became known in Europe when JM Charcot paid attention to it and published a special short monograph on this subject in 1889 . This work was translated into English (1889) and Russian (1890) and the method became popular in the treatment of tabes dorsalis and other neurological diseases. The eminent Russian neurologist VM Bekhterev proposed the combination of body suspension with cervical traction (1893). Some years later Gilles de la Tourette promoted the use of spinal traction in his neurological clinic (1897). Unfortunately neurologists worked without the cooperation of orthopedic specialists.

During the first decades of the 20th century suspension was also replaced by traction in neurology. This method was used by both neurologists and orthopedic specialists but in the last decades neurologists lost their interests in it and it found greater use in traumatology and in spinal surgery where it is still in use today.
\end{abstract}

Keywords: spinal fraction; neurological disorders; orthopedic equipment; history of medicine

\section{Introduction}

Both spinal and skeletal traction methods have a long history. The development of skeletal traction has been described in some detail ${ }^{1,2}$ while the history of spinal traction gained less attention. The idea was known from the time of Hippocrates and Galen but it only became fully implemented in modern times. In this study the history of modern spinal traction will only be considered for the last 200 years.

Since Antiquity individual enthusiastic medical men including Glisson in the 17th century and Erasmus Darwin at the end of the 18th among several other physicians were trying to apply traction for certain spinal disorders. Lack of adequate technical means and of correct anatomical knowledge led to unsuccessful results and gave birth to a popular saying that 'hunchback will only be cured by the grave'. But the idea survived over two millennia and by the end of the 18 th century it had proved to be useful. In 1789 JeanAndré Venel $(1740-1791)$ of Switzerland introduced lit à extension, the extension bed for scoliosis treatment by traction and countertraction in the horizontal position. ${ }^{3}$ Venel used a tight cap with a hook and armpit loops, all fixed to the head of the bed, for traction and a pelvic girdle with straps, fixed to the lower end of the bed, for countertraction. The external view of the device was closer to the naive devices of the previous century. Venel considered his bed as 'exclusively' his own method. ${ }^{4}$ The next step towards modernization was made by other physicians. In 1810 the German physician D Schreger offered the modern looking spinal traction bed. ${ }^{5}$ The device had a waist-belt and a head halter. The pelvic end was fixed and the spinae distorsio was performed by neck traction (Figure 1).

Orthopedics was not yet an independent medical discipline. Contemporary surgeons preferred to treat spinal diseases, traumas and even dislocations by corsets. These corsets, in the beginning, were rather crude. A typical 'machine for supporting the head and shoulders' of that time consisted of 'an iron collar, properly covered, for passing round the neck' and 'a broad iron plate, fitted to the back and shoulders' ${ }^{6}$

It does not mean, of course, that the method was totally forgotten since the time of Hippocrates' scamnium. Even Glisson's halter was introduced in the 1600s. Glisson used spinal traction in the 17th century to correct spinal deformity, and of course was by no means the first to attempt this. In fact, from the beginning of the 19th century spinal traction had been an integral part of the surgical armamentarium for the 
treatment of deformity. But during all of that time this useful method was not enforced with proper mechanical devices. Furthermore, the inventors of new machines often made no references to the previous ones. Thus, $M$ Andry in France treated rickets by suspension using a bandage across the chest, under the axillae and crossed under the chin (1743). This was a replica of Glisson's sling of the 17 th century but Andry did not mention Glisson. ${ }^{7}$ Venel also pointed out that his method 'is exclusively my own and the basis of my particular treatment'. D Schreger also produced his traction bed without any reference to previously used machines.

\section{The traction bed}

Schreger's invention did not attract immediate medical attention. But in 1825 CA Maisonabe designed nearly the same bed (Figure 2). Schreger counted his device as a short-term procedure, but Frenchman Maisonabe offered it for long-term purposes. At the same year two other French surgeons Lafond and Duval invented both traction bed and traction chair with weights. Their apparatus were described also in English in London Medical and Physical Journal for December $1826 .{ }^{9}$ At the same time the English physician D Shaw designed a traction bed with sliding frame and weights. ${ }^{10}$

The main indications for spinal traction at the beginning of the 19th century were scoliosis, backache of different origins and locations, rickets and spinal deformities. ${ }^{11}$ The new generation of inventors also tried to make the procedure less painful and more comfortable. Maisonabe even presented a picture (Figure 2) showing a woman quietly reading a book during the procedure.

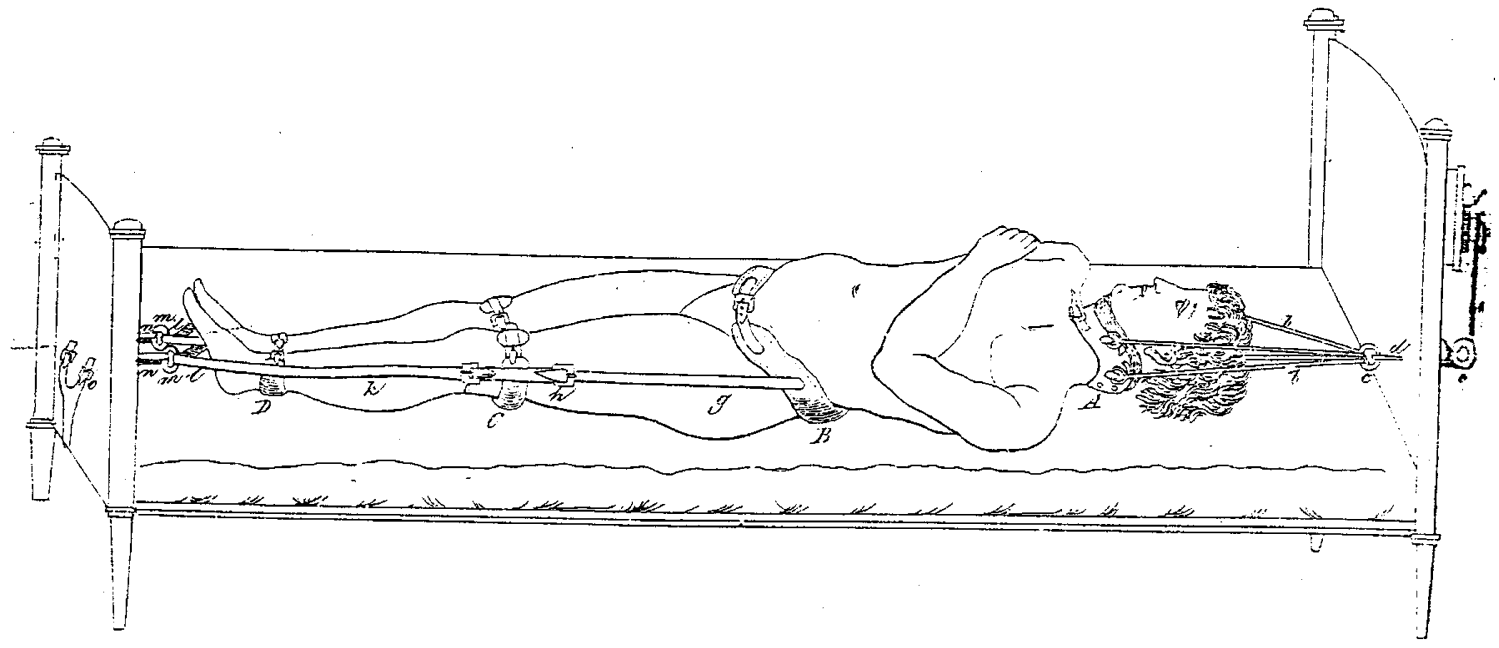

Figure 1 The spinal traction device of DBG Schreger. From Schreger DBG, 1810

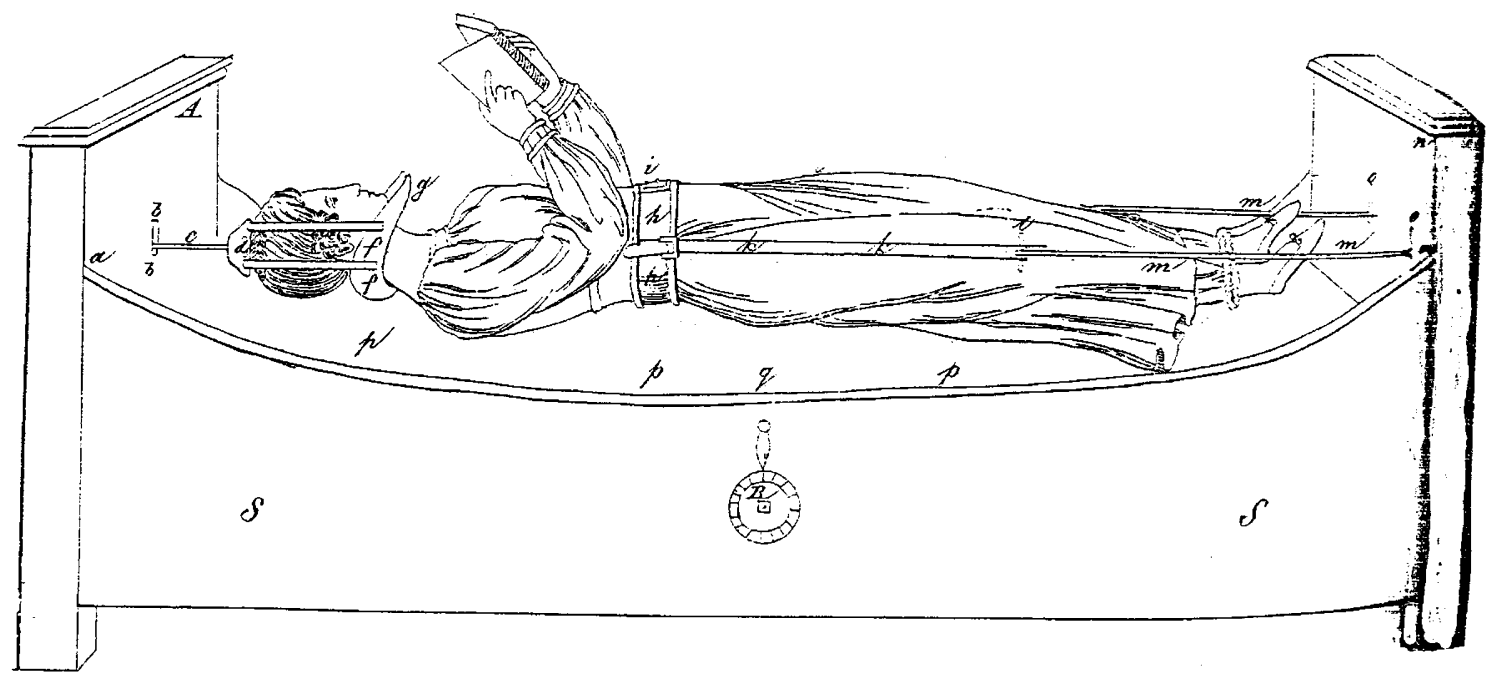

Figure 2 The French spinal traction device of CA Maisonabe. From Maisonabe CA, 1825 
Approximately at the same time (1828) JM Delpech in France applied head traction and pelvic countertraction for the patient while supine in his treatment for scoliosis ${ }^{12}$ and Ch-G Pravaz designed a bed with progressive extension (1827). ${ }^{13}$

All these English, German and French devices are surprisingly modern-looking. They are even more complicated than those of the 20th century. But the method did not become popular. The contemporary Dictionary of Practical Surgery ${ }^{14}$ did not even mention it. Despite the efforts of some individual surgeons the corsets were still the main mechanical device for spinal column care.

\section{Traction corsets}

The idea to combine corset with traction treatment goes back to the 18th century, to the appliances of F-G Levacher, who devised a spinal corset incorporating head traction (1764) and similar looking 'daytime appliance' for spinal curvature of Venel (1789). ${ }^{15}$

In the 19th century A Bonnet in France tried to obtain some traction by using a corset. In 1845 he was able to achieve some success in treating a curved spinal column by using a slowly elongated corset with neck collar, but only in the case of a young child. ${ }^{16}$

In general, orthopedic corsets of the 19th century were of little value. 'Spinal supports of all kinds corsets, mechanical appliances, particularly the 'spinal assistant' of Charles Fayette Taylor - were pure 'make-believe', because they did not and could not relieve the spinal column of its weight-bearing function'. 17

Nevertheless, the corsets were constantly improved.

In the last quarter of the 19th century the most popular of them was the one devised by the New York orthopedist LA Sayre (1820-1900). Sayre's corset, a plaster jacket, was in fact applied under suspension. But Sayre himself used suspension not for treatment but only to prevent folds on a closely-fitting undershirt. ${ }^{18}$ The method was also well known in America and in Europe because Sayre's book on the subject was published in the USA and in Great Britain at the same time. ${ }^{19}$

Sayre tried to treat Pott's disease, with good results, and scoliosis with less impressive results. ${ }^{20}$ The weak point of his book was that he did not mention his predecessors.

\section{Body suspension}

But there was a procedure with ability to 'relieve the spinal column of its weight-bearing function'. This procedure was body suspension and this method entered medicine through the gates of neurology.

In the second half of the 19th century, neurology, then a newborn independent clinical discipline, was facing therapeutic nihilism. Materia medica was useless for more than a half of nervous diseases. Trying to confine therapeutic nihilism to pharmacolo- gical means, physicians investigated other possible methods of treatment - electrotherapy, hydrotherapy, physical therapy, even acupuncture. In this context was neurological spinal traction invented.

Actually, the history of neurological spinal traction begins with body suspension. In 1883 the leading Russian medical journal Vratch ('The Physician') published the long article of Osip Mochutkovsky entitled: 'Application of the patient's suspension to the treatment of several spinal disorders'. O Mochutkovsky was a gifted medical inventor. For example, he created a 'tactsiometer' - a special device to test sensation. In 1883 he worked as a physician in the neurological division of the Odessa City Hospital, and in 1893 became professor of neurology in $\mathrm{St}$ Peterburg.

Mochutkovsky used Sayre's corset for suspension below the arm-pits with a collar-like neck fixation. ${ }^{21}$ He tried to cure 23 patients with this method, 15 of them had Tabes dorsalis (locomotor ataxia). Others had lateral sclerosis, ischias (sciatica) and chronic myelitis. He succeeded in obtaining a body elongation of up to $5 \mathrm{~cm}$ and vertebral elongation of up to $2.5 \mathrm{~cm}$. The most vivid results were achieved by Mochutkovsky for patients with tabes; there was a decrease of pain, an improvement in walking, and even reduction of the intensity of Romberg's sign. ${ }^{22}$ He observed no significant side-effects and proposed suspension for the cure of tabes dorsalis. The syphilitic origin of that disease was still doubtful in 1883, tabes was incurable and Mochutkovsky proposed suspension as a successful palliative method.

This article did not attract much attention in Russia. Mochutkovsky was then using suspension in the Odessa City Hospital alone. Happily it happened that in October $1883 \mathrm{~F}$ Raymond, pupil and future successor of JM Charcot, visited Odessa on his trip through Russian neurological clinics. Mochutkovsky demonstrated to him his method and Raymond was impressed. Upon returning to Paris Raymond informed Charcot about the suspension technique. Charcot was quick to test out the new method. Already in January 1889 he officially approved it and 1-month later reported about 40 patients with Tabes dorsalis cured by suspension. ${ }^{23}$ His work was immediately translated into English. ${ }^{24}$ One year later Charcot reported about 100 patients treated with suspension with good results. This work was also translated into Russian ${ }^{25}$ and thus Mochutkovsky's method achieved adequate feedback and became known in his own country.

Charcot and his pupil Gilles de la Tourette improved the neck collar and made it look more like the modern head halter cervical traction device (Figure 3). Like most contemporary clinicians, Charcot had little regard for pharmacological therapies, he was therefore trying to find other methods of treatment. He tried hypnosis for hysteria and almost failed, he invented a special helmet to treat migraine and totally 
failed, he proposed the vibration armchair for Parkinson's disease and failed again. But suspension was successful and Charcot started to use it very widely. One of his patients had the suspension procedure performed every day for 3 years, more than 1000 times. $^{26}$

Both Charcot and Mochutkovsky believed that the success of the treatment was a result of slight extension of nerve roots and the improvement of spinal blood circulation. Neither Sayre or Mochutkovsky mentioned the works of orthopedists. Therefore Charcot cited only Sayre and Mochutkovsky.

After 1890 a wide discussion began on the method. ${ }^{27}$ Several professors such as JM Charcot and $\mathrm{G}$ Gilles de la Tourette in France, W Erb and A Eulenburg in Germany, $M$ Benedict in Austria, VM Bekhterev in Russia, $\mathbf{J}$ Althaus in Britain greatly favoured suspension. However, W Gowers (Britain)

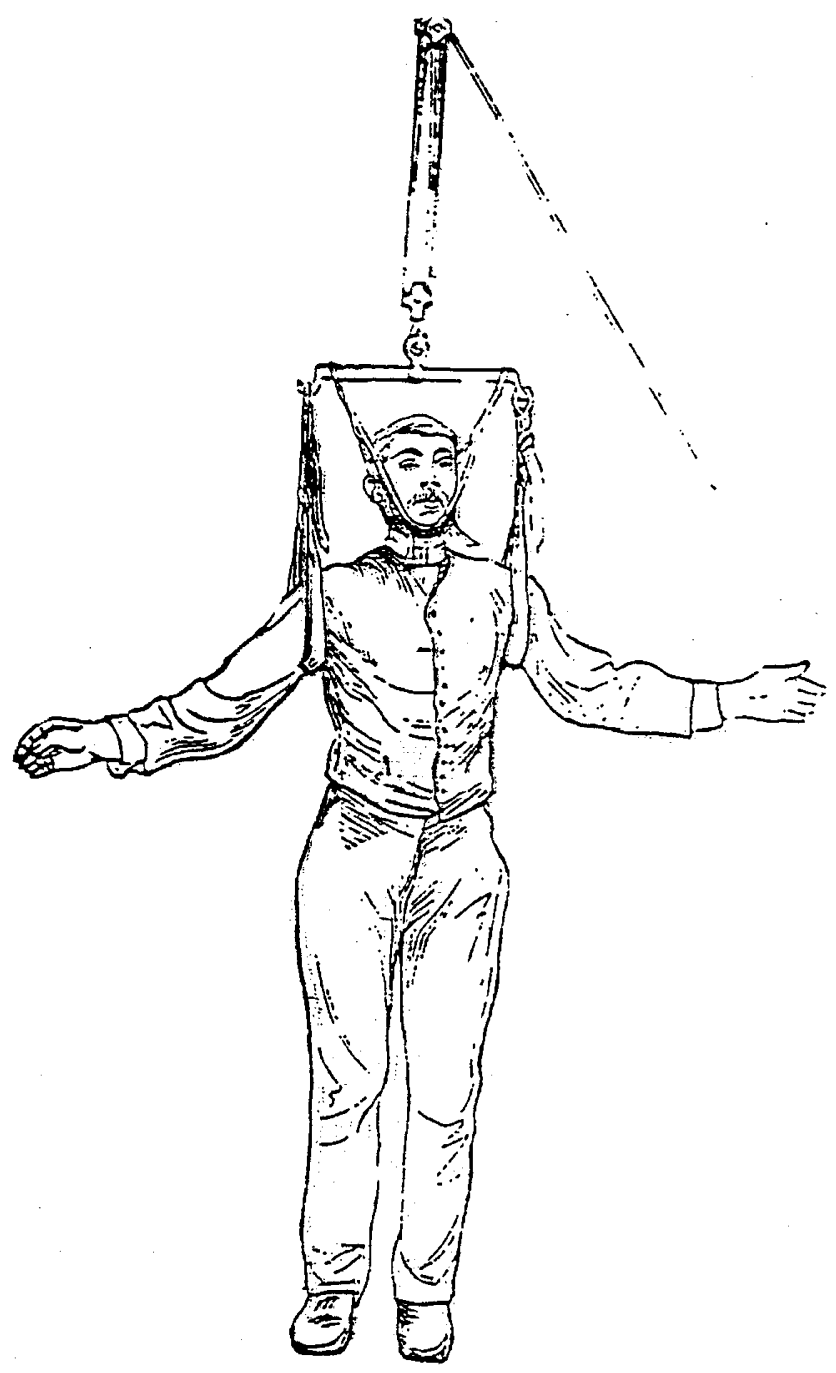

Figure 3 The Mochutkovsky - Charcot suspension technique. From Charcot JM, 1890 and A von Strumpell (Germany) had a negative opinion as several articles ${ }^{28}$ described patient's death in the neck halter's loop during self-suspension at home. The German professor E von Leyden (18321910) prohibited the method in his Berlin clinic. The American Neurological Society's reaction was also negative. $^{29}$ Critics said that this method was nonphysiological and caused local spinal hyperemia.

Something then had to be done in order to improve the method and the eminent Russian neurologist VM Bekhterev proposed the combination of suspension with traction. In his main article on that theme, published in $1893,{ }^{30}$ he described the improved neck halter and suspension from the elbows of the seated patient (Figure 4). He started to use weights. Basically he used cervical traction with some body suspension. From a modern point of view this method was not very comfortable but it was a step forward. Another of Bekhterev's innovations was an application of the method for other spinal problems. Degenerative disc disease was unknown at that time, but Bekhterev found suspension to be useful for the treatment of lumbago and sciatica. His pupil BI Voroteensky

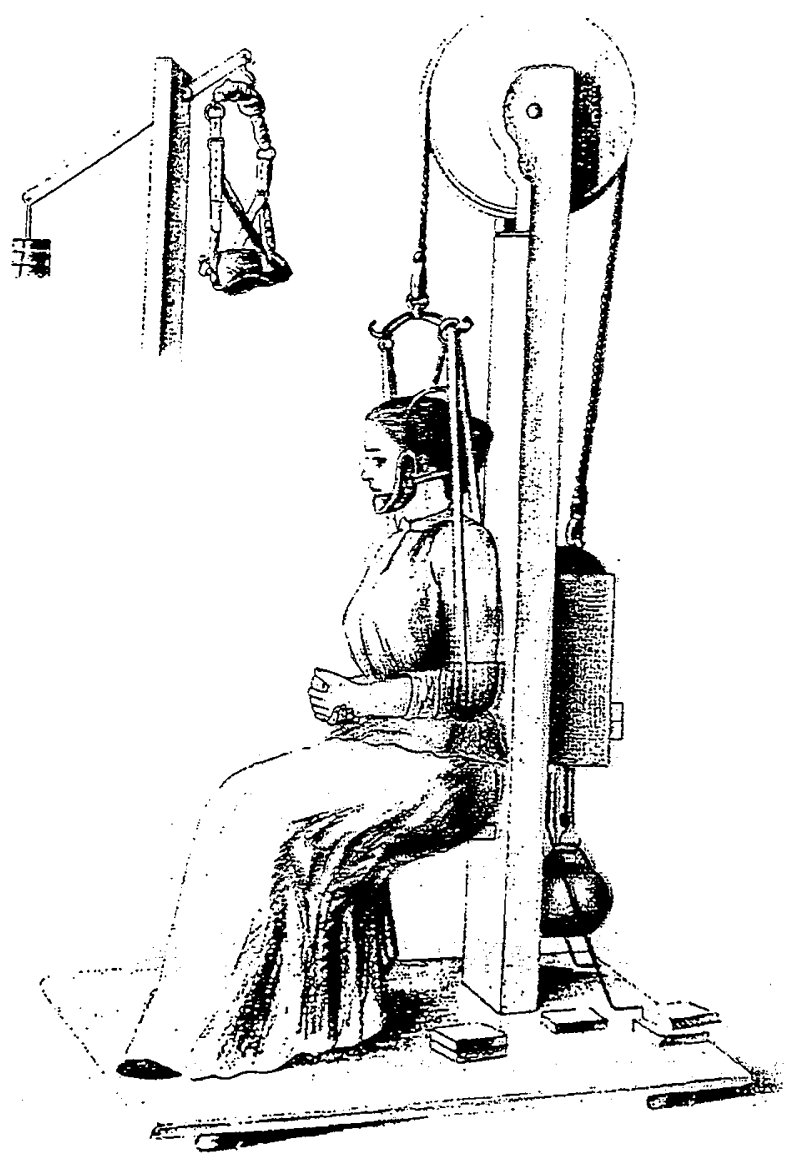

Figure 4 Bekhterev's technique of suspension with cervical traction. From Bekhterev VM, 1893 
investigated the usefulness of suspension for lower back pain and neck pain of different origins. ${ }^{31}$ In 1895 he proposed horizontal spinal traction for the treatment of compression myelitis. ${ }^{32}$

\section{Suspension vis a vis traction}

At last in 1897 Gilles de la Tourette created his own spinal traction device for sitting patients with several belts and weights (Figure 5). The patient was bent forwards and a gravity method of suspension changed to traction with carefully gauged weights. The suspension method then became obsolete and spinal traction spread widely in neurological clinics.

It did not mean, of course, that suspension treatment immediately disappeared. In France it was in use even in the 1920s. The Larousse Médical dictionary even included a picture of self-suspension. The indications were tabes, Parkinson's disease, neurasthenia with vertigo, and impotence. ${ }^{33}$

Americans were still rather reticent toward the method. 'Suspension was recommended by Mochutkovsky in 1883. In the decade following, neurologists of every nationality testified to its efficacy in ameliorating the symptoms of tabes and apparently in modifying the course of the disease. During the past few years very little had been heard of it, and its use has been generally discontinued', - a reported serious American therapeutic manual in $1926 .{ }^{34}$
As for suspension the manual was correct, but spinal traction was proceeding. Two main problems were then prevalent: to choose the correct indications and to find a reasonably safe technique for the procedure. The main indication, tabes dorsalis, was out of the question for two reasons. The first was undoubtedly the fact that a new pharmacological treatment for syphilis (Salvarsan, etc) was developed and all other palliative means were abandoned. The second was that tabes became very rare in the middle of our century. The indications shifted to the numerous syndromes involving neck and low back pains and to sciatica, as neurologists still maintained that the cure of back pain was under their own sole responsibility.

It is a strange fact that neurologists such as Charcot or Gilles de la Tourette, inventing their own above mentioned devices, never wrote about the same use by orthopedists.

\section{Skeletal traction}

Neurologists, of course, did not take up skeletal traction, as the main indications for this method are for different fractures of the bones. In fact the history of modern skeletal traction starts at the end of the 19th century when aseptic and antiseptic measures were introduced to medicine. Since that time the use of rods and screw hooks became possible without infectious

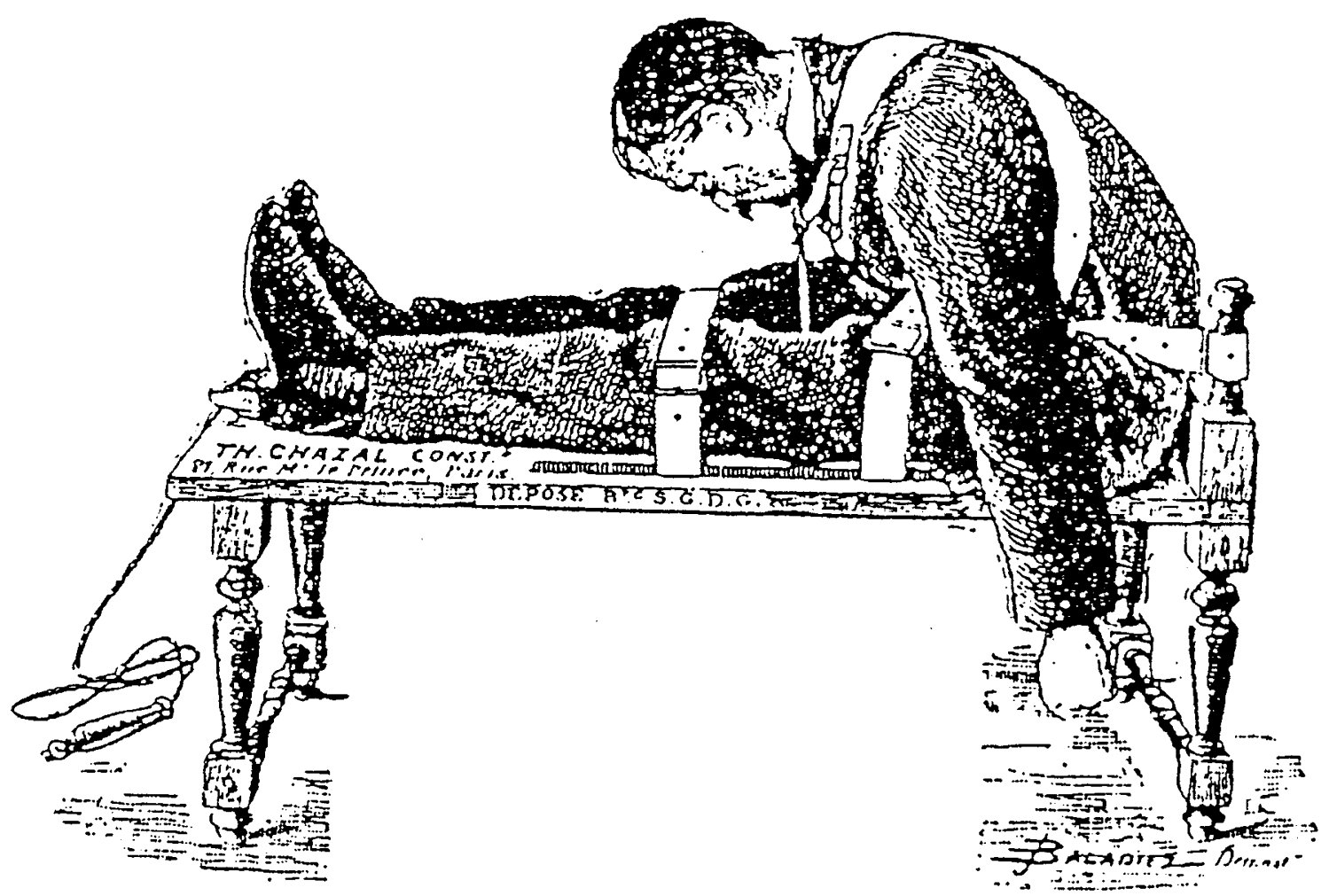

Figure 5 The spinal traction technique of Gilles de la Tourette. From Gilles de la Tourette G, 1898 
complications. At this same time, orthopedic specialists tried to improve the spinal traction.

The safety of the procedure was the second important problem for neurologists, neurosurgeons and orthopedists. The chin-head halter traction was the weakest point of the method. The skin can hardly tolerate traction of more than 2.5 to $3 \mathrm{~kg}$ ( 5 to $6 \mathrm{lbs}$ appr.) for a long period of time because of the danger of skin necrosis of the chin and occipital regions. When Glisson's Head Halter was introduced into practice the problem was not yet solved. The torques of Antonius Nuck (1696) and Erasmus Darwin's 'neck swing' (1796) along with devices of M Langenbeck (1850) and Charcot (1890) are just a few attempts to improve the head halter but the problem still remained. Due to constant improvement of the device traction became extremely popular in the middle of our century. An Atlas of Orthopedic Traction Procedures dated 1954 shows numerous traction devices indications and positions. ${ }^{35}$ Most chapters are dedicated to skeletal traction with a screw hook. These surgical procedures are somewhat removed from neurological spinal traction. Skeletal traction, therefore, has its own history, especially concerning the techniques.

Pre-operative spinal traction was used widely in Europe from the 1920 s, although much less so in America.

Spinal traction is still useful for surgery of the spine. In the 1970s traction using Glisson's head halter and pelvic straps of a pelvic girdle and continuous traction in bed with a sliding frame (semi-traction - semisuspension - MV Sh.) were prescribed in the preoperative stage (Figure 6). ${ }^{36}$ The method has been rarely used since the introduction of modern surgical spinal instrumentation. The method of skeletal traction applied to the spine for the treatment of scoliosis is known today as Kinder-Harrington rodding. ${ }^{37}$ Moreover, halo-femoral traction is used for spinal deformities with neurological complications. $^{38}$

The method is also used in traumatology (eg from car accidents), and in manual medicine there is the method of spinal non-skeletal autotraction. ${ }^{39}$

However, spinal traction now seems to be lost for neurology. 'Many of us recall the days when patient after patient would be admitted to hospital for traction. Fortunately, the cost of such treatment and the lack of scientific basis have largely put an end to such a useless endeavor', - this is a quotation from Backache second edition in $1990 .^{40}$ 'Pelvic traction generally has not been found effective except to help enforce strict bed rest', - echoes the Manual of Neurology in 1992. ${ }^{41}$ These two quotations sound like a verdict against the use of spinal traction in the neurological clinic. Russia is perhaps nowadays the only country where spinal traction is still used in a neurological context. Thus a modern Russian neurological textbook advises "traction therapy on a sliding frame by using the body weight of the patient (timid suspension - MV Sh.), traction in bed with nonspecific devices, traction in water with weights (another kind of timid suspension) and traction with technical devices' in case of backache. ${ }^{42}$

In surgery and traumatology, however, skeletal traction became a part of cervical traction procedures. After the development of antiseptic and later aseptic measures, the development of local anesthesia became the second important step in this direction. When preventive measures against infection and pain complications had been secured, skeletal traction became the best method of cervical traction for use over prolonged periods of time.

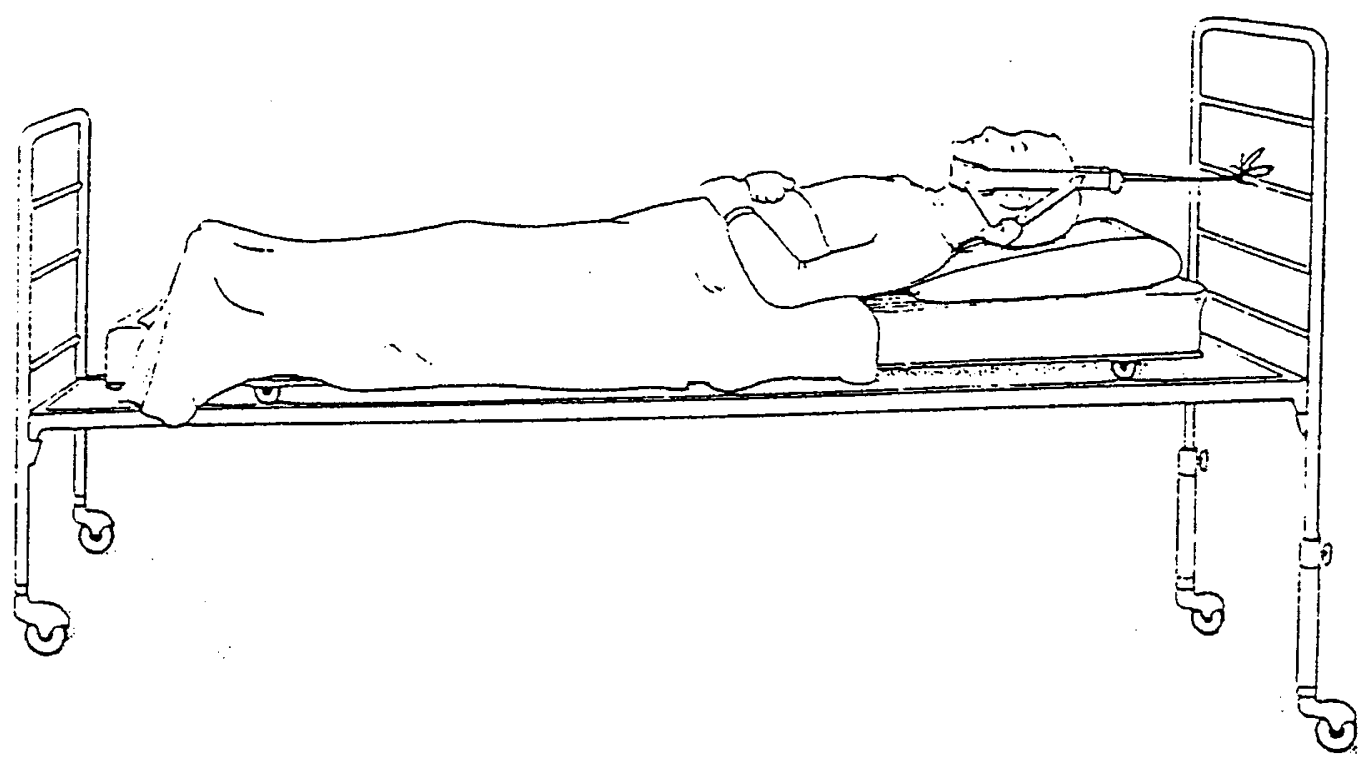

Figure 6 Continuous traction in bed technique with Glisson's Head Halter and traction bed with sliding frame. From Rathke FW, Schlegel K-F, 1979 
It was mentioned above that the main complications of halter cervical traction were pressure sores under the chin and behind the occiput especially when applied for long periods or when used with heavy weights. ${ }^{43}$ Skeletal traction was free from such complications.

The third step in the history of skeletal traction was an improvement of the instrumentarium. In 1933 Neubeiser fish hooks for zygomatic traction, and Crutchfield tongs were introduced simultaneously. Subsequently, the tongs of Cone and Turner (1937), Barton (1938), Vinke (1948) and Merle d'Aubigné (1958) were produced. These tongs were applied to the skull above and in front of the ears (according to AG Hardy and AB Rossier, 1975) had had the advantage of not penetrating deeply into the parietal bone. ${ }^{44}$

Nevertheless, the possibility for skull tongs to penetrate the cranium and brain tissue was the main complication of the method until the beginning of the 1980s and only the Gardner-Wells tongs significantly decreased the risk because of the improvement of their shape and the control of pressure.

\section{The present use}

Once clinical neurology abandoned such devices, the main indication for spinal traction became the reduction of deformities after different spinal column injuries. Horizontal or diagonal traction with carefully applied weights control replaced vertical suspension in which the main weight was the weight of the patient's body.

In practice traction is mainly used in cervical spine trauma management. For the purpose of cervical spine stabilisation the insertion of skull calipers is used with the application of $1-5 \mathrm{~kg}$ of traction, according to the level of the injury. ${ }^{45}$ The different types of skull calipers and their advantages and disadvantages are beyond the scope of this article as they are used more for external stabilisation than for traction. Spinal traction for the treatment of low back pain is now used as a form of spinal manipulation of the lumbar and thoracic spines mainly in the fields of osteopathy, physiotherapy and chiropraxis. ${ }^{46}$

\section{Conclusion}

While the history of spinal traction in neurology has come to an end, the general history of the method, spreading in its modern part over 200 years, shows an unusual evolution by moving from one medical discipline to several others, including neurosurgery, and is still under intensive development.

\section{Acknowledgement}

Research conducted with the support of the Joshua \& Hannah Leibovitz Fellowship Fund.

\section{References}

1 Bick EM. History and Source Book of Orthopaedic Surgery. The Hospital for Joint Diseases: New York, 1933, pp. 7, 32, 42, 132, $133,144,145$.

2 Rang M. Anthology of Orthopaedics. E \& S Livingstone Ltd: Edinburgh \& London, 1966, pp. 160-167.

3 Le Vay D. The History of Orthopaedics. The Parthenon Publ. Group: Carnforth, Lancs \& Park Ridge, New Jersey, 1990, pp. 299,533 .

4 Ibidem, p. 533

5 Schreger DBG. Versuch eines nächtlichen Streckapparats für Rückgratgekrümmte. Erlangen 1810.

6 Waters NB. A system of Surgery, extracted from the works of Benjamin Bell. Budd and Bartram: Philadelphia 1802, Plate XII, fig. 6 .

7 Le Vay D, 1990, p 235.

8 Ibidem, p. 533.

9 [Anonymous]. Chirurgische lithographirte Tafeln zum Gebrauch für Practische chirurgen. Vg. Andreas Kienreich [without place] 1826, tab. 94.

10 Ibidem, tab. 95

11 Le Vay D, 1990, pp. 95, 233, 239, 243, 530-541.

12 Ibidem, p. 243.

13 Ibidem, p. $248-249$.

14 Cooper S. A Dictionary of Practical Surgery. Longman \& Co.: London, 1822.

15 Le Vay D, 1990, pp. 239, 242, 298.

16 Bonnet A. Traité des Maladies des Articulations. Tome 2. Paris Lyon 1845 , pp. $543-547$.

17 Keith A. Menders and Maimed. Hodder \& Stoughtton: London 1919, p. 177.

18 Ashhurst S. Review on Spinal Disease and Spinal Curvature. Their Treatment by Suspension and the use of the Plaster of Paris Bandage, by Lewis A Sayre, 1878. Amer J Med Sci 1878; vol. 75: 455.

19 Sayre LA. Spinal Disease and Spinal Curvature. Their Treatment by Suspension and the use of the Plaster of Paris Bandage. Elder \& Co.: London; JB Lippincott \& Co.: Philadelphia, 1878.

20 Ashhurst S, 1878, pp. 457-458.

21 Mochutkovsky OO. Application of patient's suspension to a treatment of several spinal disorders. Vratch 1883; 17-21: 258 $259,278-280,294-295,309-311,324-325$ [Russian].

22 Ibidem, p. 324

23 Gilles de la Tourette G. Leçons de Clinique Thérapeutique sur les Maladies du Système Nerveux. E Plon, Nourrit et Cie.: Paris, 1898 , pp. $460-475$.

24 Charcot JM. On the treatment by suspension of locomotor ataxy and some other spinal affections. Stott: London, 1889

25 Charcot JM. On the treatment of tabes dorsalis by Mochutkovsky's method of suspension. Practicheskaya Medicina: St Petersburg 1890, [Russian].

26 Mochutkovsky OO. Lectures on locomotor ataxia, delivered in the Clinical Institute of Great Duchess Elena Pavlovna in $1896-$ 97. Vratch 1898; 28: $822-825$, [Russian].

27 Russell JSR, Taylor J. Treatment by suspension. Brain 1890; 13: $207-223$.

28 Mochutkovsky OO. 1898, p. 822

29 Ibidem, p. 823.

30 Bekhterev VM. The meaning of suspension for several spinal disorders. Neurologichesky Vestnik 1893; 1: 15-20 [Russian].

31 Voroteensky BI. Spinal traction in horizontal position for compression myelitis. Neurologichesky Vestnik 1895; 3: 99 105, [Russian].

32 Voroteensky BI. Suspension as method of treatment for nervous diseases. Neurologichesky Vestnik 1893; 1: 21 -30, [Russian].

33 Suspension. In: Galtier-Boissière, ed. Larousse Médical Illustré. New edn. Larousse: Paris, 1924, p. 1166, [French].

34 Blumer $\mathrm{G}$, ed. The George Blumer Edition of BillingsForchheimer's Therapeusis of Internal Diseases. Vol. VI. D Appleton \& Co.: New York - London, 1926, p. 224.

35 Scuderi C. Atlas of Orthopedic Traction Procedures. The CV Mosby Company: St Louis, 1954, pp. 13-14, 54-55. 
36 Rathke FW, Schlegel K-F. Surgery of the Spine. Georg Thieme Publ.: Stuttgart, 1979, p. 99.

37 Polster J, Heine J, Strick-Lutterman D, Kinder-Harrington rodding. In: Warner JO, Matha MH, ed. Scoliosis Prevention Proceedings of the 7th Phillip Zorab Symposium. Praeger: New York, 1983, pp. 141-145.

38 Winter RB. Spinal deformities at risk for neurological complications. In: Warner JO, Metha MH, ed. Scoliosis Prevention - Proceedings of the 7th Phillip Zorab Symposium Praeger: New York, 1983, pp. 247-248.

39 Brugnoni G, Leuci C. The method of autotraction in manual medicine. In: Paterson JK, Burn L, ed. Back Pain - an International Review. Kluwer Academic Publ. Dordrecht/ Boston/London, 1990, pp. 227-230.

40 Macnab I, McCulloch J. Backache. 2nd edn. Williams \& Wilkins: Baltimore/Hong Kong/ London/Sydney, 1990, p. 267.

41 Hinton RC. Backache. In: Samuels MA, ed. Manual of Neurology, 4th edn. Little, Brown \& Co.: Boston/Toronto London, 1992, p. 75

42 Gusev EI, Grechko VE, Burd GS. A Textbook on Nervous Diseases. Medicina: Moscow, 1988, p. 368, [Russian].

43 Hardy AG, Rossier AB. Spinal Cord Injuries. Orthopedic and Neurological Aspects. Georg Thieme Publ. Stuttgart, 1975, p. $44-46$

44 Ibidem, pp. $48-49$.

45 El Masri WS, Jaffray D. Recent developments in the management of injuries of the cervical spine. In: Vinken PJ, Bruyn GW, Klawans HL, Frankel HL, ed. Handbook of Clinical Neurology, Vol. 61: Spinal Cord Trauma. Elsevier Science Publishers: Amsterdam/London/New York/Tokyo, 1992, p. 61.

46 Bourdillon JF. Spinal Manipulation. 2nd edn. William Heinemann Ltd.: London; Appleton-Century-Crofts: New York, 1973, pp. $70-72$ 